\title{
BUSINESS FIXED INVESTMENT IN H1 2016
}

\author{
O.Izryadnova
}

In $H 1$ 2016, business fixed investment stood at $95.7 \%$ against the corresponding period of the previous year. Reduction in the scale of investment and construction activity is due to pattern of adaptability of economic entities to the current situation in the economy. The segment of large and medium enterprises faces a gradual easing of recession: during January-June 2016 against the corresponding period of the previous year, business fixed investment shrank by $1.0 \%$. In the current environment small enterprises responded with derailing construction and investment activity. Upward trend in the share of own funds with a reduction of borrowed capital has strengthened in the structure of the investment financing sources.

Business fixed investment of large enterprises in the mining sector went up by 7.5\% in $\mathrm{H} 12016$ against the corresponding period of the previous year. Manufacturing industry and infrastructure sectors have demonstrated enhancement of recession along quarters of the current year.

This year the situation in the investment sector of the economy is determined by a fall of business investment in the course of last thirteen quarters. In H1 2016, business investment stood at $95.7 \%$. The scope of works completed in the construction sector comes to $94.3 \%$ against the corresponding values of 2015. Business expectations and projections regarding domestic investment demand are not very optimistic and somewhat easing of dynamics of slowdown of investment and construction activity volume is due to pattern of adaptability of economic entities to changing conditions. In the segment of large and medium enterprises gradual easing of recession through quarters resulted in the decrease of business fixed investment by 1.0\% for January-June 2016 against the corresponding period of the previous year. Decrease of the entrepreneurial confidence and small businesses' profits enhanced the process of derailing investment and construction work.

In H1 2016, business fixed investment saw growing share of investment in construction of residential and industrial buildings as the share of investment in machines and equipment stabilizes. Redistribution of investment funds along capital stock in the current year was affected by a price correlation on the investment products. Following price hike on purchase of machines and equipment of the investment purpose by $20.1 \%$ and on the construction services by $4.1 \%$ in June 2015 against December of the previous year, price indices hit 102.3 and $102.0 \%$, respectively.

Situation with ensuring commissioning of industrial facilities is hampered by simultaneous decrease of domestic production and imports of capital machinery and equipment. Taking into account the difference in the technological structure of business investment along facilities of industrial and nonindustrial purpose the most significant reduction of the construction work was observed in industry and agriculture.

In $\mathrm{H} 12016$, investment in transactions with real property went up by $8.2 \%$ in comparison with the same period of the previous year. The structure of 


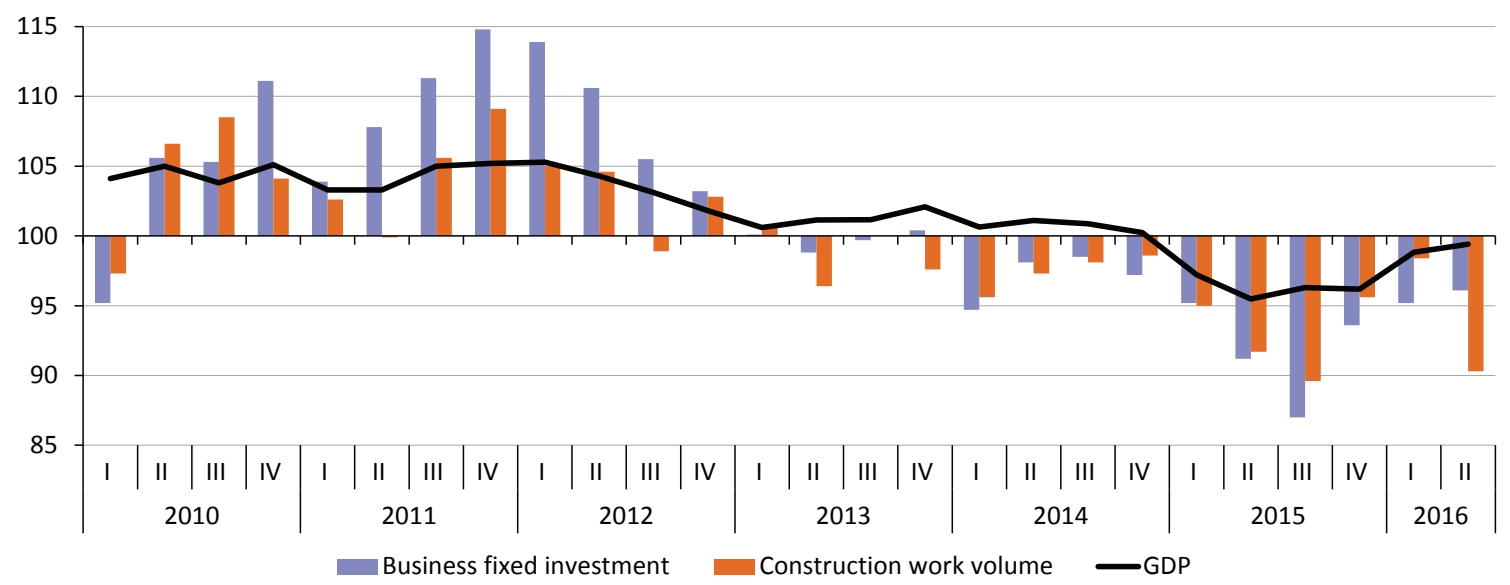

Source: Rosstat.

Fig. 1. Dynamics of fixed capital investment in 2011-2016, \% to the corresponding quarter of the previous year

financing of residential housing in 2012-2016 saw changes owing to the increase of volume and share of the population's funds in the cost sharing residential housing construction amid growing reduction of funds invested by organizations. In Q2 2016, somewhat decreased trend of the investment activity growth of the population recovered and by H1-end 2016, the funds received for the cost sharing construction moved up by $\mathrm{Rb} 12.8 \mathrm{bn}$. Growing investment activity of the population was accompanied by demand increase on housing and mortgage loans by 1.45 times in comparison with H1 2015 . It should be noted that amid general trend to a reduction of the population's income and contraction of savings ratio, growing credit activity of the population is accompanied by outstanding debt growth on housing loans. Increased share of investment in construction of non-residential buildings in the current year was determined by an increase in volumes of work and commission of industrial and agricultural buildings amid reduction of construction activity in administrative, commercial, and social spheres.

Increased commissioning of industrial buildings determines a change in the technological structure of investment and predetermines demand

\section{STRUCTURE OF BUSINESS FIXED INVESTMENT AS BROKEN BY TYPE \\ OF CAPITAL STOCK IN H1 2012-2016 (LESS SMALL BUSINESS AND INFORMAL ACTIVITY PARAMETERS), \% TO TOTAL}

\begin{tabular}{|c|c|c|c|c|c|c|c|c|c|c|}
\hline & \multicolumn{5}{|c|}{$\mathrm{Rb}$ bn in current prices } & \multicolumn{5}{|c|}{$\%$ to total } \\
\hline & 2012 & 2013 & 2014 & 2015 & 2016 & 2012 & 2013 & 2014 & 2015 & 2016 \\
\hline $\begin{array}{l}\text { Business fixed } \\
\text { investment }\end{array}$ & 3135.0 & 3356.1 & 3579.4 & 3632.5 & 3920.9 & 100 & 100 & 100 & 100 & 100 \\
\hline Residential housing & 133.7 & 166.7 & 215.8 & 205 & 239.1 & 4.3 & 5.0 & 6.0 & 5.6 & 6.1 \\
\hline $\begin{array}{l}\text { Buildings (other than } \\
\text { residential buildings) } \\
\text { and facilities }\end{array}$ & 1601.9 & 1644.9 & 1764.9 & 1932.9 & 1876.9 & 51.1 & 49.9 & 49.3 & 47.7 & 47.9 \\
\hline $\begin{array}{l}\text { Machines, } \\
\text { equipment, and } \\
\text { means of transport }\end{array}$ & 1146.9 & 1241.8 & 1228.7 & 1240.6 & 1347.2 & 36.6 & 37.0 & 34.3 & 34.2 & 34.3 \\
\hline Other & 116.9 & 130.4 & 370.0 & 454.0 & 457.7 & 8.0 & 9.0 & 10.4 & 12.5 & 11.7 \\
\hline
\end{tabular}

Source: Rosstat. 
growth for machinery and equipment. However, comparison of dynamics of domestic manufacture of equipment, imports of capital goods and business fixed investment demonstrates that in existing dynamics of machine-building complex operation and in the wake of retention of sanctions on imports of certain types of equipment and machinery the balance of technological structure of investment is disrupted. Structural changes in goods import in H1 2016 in increasing the share of investment goods to $23.6 \%$ (+2 p.p. to last year's indicator) resulted in somewhat ease decline in the investment activity. However, these changes failed to offset slump in domestic production of machines and equipment.

Financing of investment was determined by increased orientation towards the use of own funds. In H1 2016, the share of investment at the expense of the enterprises' own funds hit $56.6 \%$ of the total volume of business fixed investment. In the context of high interest rates in order to optimize costs enterprises favored the use of own funds. Although in Q1 2016, profitability in the economy as a whole fell by 1.4 p.p. against the corresponding period of the previous year.

In H1 2016, borrowed funds from the banks earmarked for business fixed investment shrank by Rb $8.1 \mathrm{bn}$. At the same time, credits issued by Russian banks have not offset contraction of credits issued by foreign banks. Foreign investment volume continued to contract in $\mathrm{H} 12016$. Predominance of busi-

Table 2

STRUCTURE OF BUSINESS FIXED INVESTMENT BY SOURCE OF FINANCING IN H1 2012-2016, $\%$ TO TOTAL (LESS SMALL BUSINESSES AND PARAMETERS OF INFORMAL ACTIVITY)

\begin{tabular}{|c|c|c|c|c|c|c|c|c|c|c|}
\hline & \multicolumn{5}{|c|}{$\mathrm{Rb}$ bn, current prices } & \multicolumn{5}{|c|}{$\%$ to total } \\
\hline & 2012 & 2013 & 2014 & 2015 & 2016 & 2012 & 2013 & 2014 & 2015 & 2016 \\
\hline Business fixed investment & 3135.0 & 3356.1 & 3579.4 & 3632.5 & 3920.0 & 100 & 100 & 100 & 100 & 100 \\
\hline \multicolumn{11}{|l|}{ By sources of financing: } \\
\hline Own funds; & 613.3 & 693.9 & 1878.7 & 2052.5 & 2217.3 & 49.3 & 50.0 & 52.5 & 56.2 & 56.5 \\
\hline Borrowed funds & 1544.0 & 1678.0 & 1700.7 & 1590.0 & 1703.7 & 50.7 & 50.0 & 47.5 & 43.8 & 43.5 \\
\hline Bank credits, including: & 262.8 & 340.5 & 369.9 & 321.7 & 313.6 & 8.4 & 10.2 & 10.3 & 8.3 & 8.0 \\
\hline $\begin{array}{l}\text { Credits from } \\
\text { foreign banks; }\end{array}$ & 49.3 & 40.1 & 51.1 & 83.1 & 71.2 & 1.6 & 1.2 & 1.4 & 2.3 & 1.8 \\
\hline $\begin{array}{l}\text { Credits from } \\
\text { Russian banks; }\end{array}$ & 213.5 & 300.4 & 318.8 & 238.6 & 241.4 & 6.8 & 9.0 & 8.9 & 5.0 & 6.2 \\
\hline $\begin{array}{l}\text { Borrowed from other } \\
\text { organisations }\end{array}$ & 165.4 & 234.8 & 243.7 & 197.1 & 301.5 & 5.3 & 7.0 & 6.8 & 5.4 & 7.7 \\
\hline Foreign investments & н/д & н/д & 25 & 34.6 & 30.7 & н/д & н/д & 0.7 & 1.0 & 0.8 \\
\hline Budgetary funds: & 412.9 & 459.8 & 444.8 & 464.7 & 481.2 & 13.2 & 13.7 & 12.4 & 12.8 & 12.3 \\
\hline from federal budget & 199.5 & 242.8 & 213.2 & 249.3 & 259.5 & 6.4 & 7.2 & 6.0 & 6.9 & 6.6 \\
\hline $\begin{array}{l}\text { from budgets of } \\
\text { RF subjects }\end{array}$ & 187.0 & 188.3 & 198.6 & 183.4 & 192.0 & 6.0 & 5.6 & 5.5 & 5.0 & 4.9 \\
\hline $\begin{array}{l}\text { Funds from extra } \\
\text { budgetary funds }\end{array}$ & 6.9 & 13.4 & 7.0 & 8.3 & 8.9 & 0.2 & 0.4 & 0.2 & 0.2 & 0.2 \\
\hline $\begin{array}{l}\text { Funds obtained for cost- } \\
\text { shared construction } \\
\text { (organizations and } \\
\text { population), including }\end{array}$ & 64.0 & 82.1 & 114.9 & 114.5 & 135.8 & 2.0 & 2.4 & 3.2 & 3.1 & 3.5 \\
\hline population's funds & 42.9 & 65.2 & 93.4 & 92.3 & 104.8 & 1.4 & 1.9 & 2.6 & 2.5 & 2.7 \\
\hline Other & 679 & 547.5 & 495.4 & 449.1 & 431.5 & 21.7 & 16.3 & 13.9 & 12.4 & 11.0 \\
\hline
\end{tabular}

Source: Rosstat. 
nesses controlled by the state as well as the low level of Russian corporate governance negatively affect the influx of foreign investors to the country.

The role of the budget funds was changing in the structure of the borrowed funds earmarked for financing business fixed investment. In H1 2016, fixed capital investment to the tune of $\mathrm{Rb} 481.2$ bn (12.3\% of the total volume of investment in the economy) were assigned from the budget funds. Compared to $\mathrm{H} 12015$, the scale of investment funding from the federal budget went up by $\mathrm{Rb} 16.5$ bn including by 10.2 bn from the federal budget funds.

Easing of the investment activity on the part of large holdings, joint stock companies and financial industrial groups with state participation in the course of 2013-2016 is telling highly negatively on the formation of business fixed investment dynamics. The share of investment disbursed from other sources of funding, the dominant share of which falls on the institutional investors with public participation, contracted by 2.4 p.p. against $\mathrm{H} 12015$ and by 10.7 p.p. in comparison with $\mathrm{H} 1$ 2012. Amid the existing interest rates, large enterprises exceptionally reservedly treat the idea of widening the scope of the investment activity and stick to the savings model. However, it should be noted that the turn of 2016 was characterized by a more significant easing of dynamics of corporate deposits against the demand on credit resources.

During 2013-2016, the structure of investment in fixed assets by types of economic activity saw rather significant changes.

The feature of $\mathrm{H} 12016$ was the growing share to $54.7 \%$ of business fixed assets in comparison with the corresponding period of the previous years. At the same time, in $\mathrm{H} 12016$, speed up in growth of investment in mining and quarrying by $7.5 \%$ against $\mathrm{H} 12015$ was accompanied with a contraction of capital investment in the manufacturing sector by $6.5 \%$ and in the production and distribution of electricity, gas and water by $7.8 \%$. As a result by $\mathrm{H} 1$ - end 2016 , the share of business investment remained at the level of the previous year.

In the context of economic recovery prolonged downward trend in investment in transport remains very warning sign, taking into account high importance of transport communications and characteristics of the technical state of rolling stock. Tightening of domestic demand has determined contraction of investment in the development of commerce, hotel industry and restaurant business.

Structural changes in the manufacturing industry were determined by a fall of business investment in the machine-building complex by $22.7 \%$, in production of coke and petroleum products - by $27.3 \%$ in comparison with $\mathrm{H} 1$ 2015.

In $\mathrm{H} 12016$, investment in chemical and timber complex went up by $13.4 \%$ and in metallurgical complex - by $23.3 \%$ against $\mathrm{H} 12015$, which is due both to an increase in export potential of these industries and to import substitution processes.

According to the forecast of socio-economic development of the Russian Federation, projected volume of investment is estimated in the range of 96.9\% (base scenario) to $90.6 \%$ (conservative scenario) compared to the previous year. The rating of challenges for the Russian investment market depends on the geopolitical situation, consistency of measures of state regulation, character of changes in spending and behavior of consumers. 
Table 3

\section{BUSINESS FIXED INVESTMENT (WITHOUT SMALL BUSINESSES AND INVESTMENT VOLUME NOT OBSERVED BY DIRECT STATISTICAL METHODS) IN H1 2012-2016}

\begin{tabular}{|c|c|c|c|c|c|c|c|c|c|c|}
\hline & \multicolumn{5}{|c|}{$\begin{array}{l}\text { Growth rate in \% to the corresponding } \\
\text { period of the previous year }\end{array}$} & \multicolumn{5}{|c|}{ Structure in \% to total } \\
\hline & 2012 & 2013 & 2014 & 2015 & 2016 & 2012 & 2013 & 2014 & 2015 & 2016 \\
\hline Total & 109.6 & 94.2 & 102.8 & 92.7 & 99.0 & 100 & 100 & 100 & 100 & 100 \\
\hline $\begin{array}{l}\text { Agriculture, hunting } \\
\text { and forestry }\end{array}$ & 106.9 & 100.8 & 103.2 & 100.2 & 109.0 & 3.4 & 3.4 & 3.4 & 3.7 & 3.7 \\
\hline $\begin{array}{l}\text { Fishery and } \\
\text { fish farming }\end{array}$ & 240.0 & 95.2 & 40.4 & 79.8 & 152.2 & 0.1 & 0.1 & 0.1 & 0.1 & 0.1 \\
\hline Industry & 118.1 & 94.8 & 104.8 & 97.3 & 100 & 51.1 & 51.3 & 52.6 & 51.6 & 54.7 \\
\hline Mining and quarrying & 117.8 & 92.1 & 105.0 & 109.6 & 107.5 & 22.3 & 22.7 & 23.4 & 23.4 & 27.1 \\
\hline Manufacturing sector & 121.5 & 100.4 & 105.7 & 94.1 & 93.5 & 17.8 & 18.2 & 19.2 & 19.9 & 19.9 \\
\hline $\begin{array}{l}\text { Production and } \\
\text { supply of electricity, } \\
\text { gas and water }\end{array}$ & 113.4 & 90.9 & 102.9 & 75.8 & 92.2 & 11.0 & 10.4 & 10.0 & 8.3 & 7.7 \\
\hline Construction sector & 97.4 & 101.5 & 92.1 & 79.4 & 100.8 & 2.3 & 2.1 & 2.1 & 1.6 & 1.5 \\
\hline $\begin{array}{l}\text { Wholesale and } \\
\text { retail commerce }\end{array}$ & 99.0 & 130.9 & 93.0 & 89.3 & 99.8 & 1.9 & 2.8 & 2.8 & 2.7 & 3.0 \\
\hline $\begin{array}{l}\text { Hotels and } \\
\text { restaurants }\end{array}$ & 81.1 & 123.5 & 144.8 & 27.4 & 94.8 & 0.3 & 0.8 & 1.0 & 0.4 & 18.6 \\
\hline $\begin{array}{l}\text { Transports and } \\
\text { communications }\end{array}$ & 99.6 & 84.1 & 100.7 & 88.6 & 94.8 & 25.3 & 21.2 & 20.2 & 19.5 & 18.6 \\
\hline Railway transport & 86.8 & 100.8 & 71.4 & 88.5 & 93.0 & 4.2 & 4.1 & 2.9 & 3.0 & 2.0 \\
\hline Pipeline transport & 92.0 & 68.1 & 116.5 & 87.9 & 80.5 & 10.0 & 6.7 & 7.3 & 6.7 & 5.3 \\
\hline Communications & 112.2 & 92.8 & 116.0 & 88.8 & 103.0 & 3.4 & 314 & 3.3 & 3.3 & 3.4 \\
\hline Financial business & 141.0 & 110.8 & 77.9 & 92.0 & 87.4 & 1.6 & 2.1 & 1.4 & 1.4 & 1.4 \\
\hline $\begin{array}{l}\text { Real estate } \\
\text { operations }\end{array}$ & 102.7 & 103.1 & 115.9 & 87.6 & 108.2 & 6.9 & 8.7 & 10.4 & 9.8 & 11.5 \\
\hline Public administration & 99.6 & 83.0 & 88.7 & 108.3 & 123.6 & 1.4 & 1.4 & 1.0 & 1.1 & 1.3 \\
\hline Education & 99.0 & 101.6 & 108.2 & 106.5 & 77.4 & 1.5 & 1.4 & 1.4 & 1.6 & 1.2 \\
\hline $\begin{array}{l}\text { Healthcare } \\
\text { and provision of } \\
\text { social services }\end{array}$ & 122.5 & 103.1 & 68.4 & 90.1 & 104.2 & 1.7 & 1.7 & 1.1 & 1.1 & 1.2 \\
\hline
\end{tabular}

Source: Rosstat. 